\begin{abstract}
"Mircea cel Batran" Naval Academy Scientific Bulletin, Volume XIX - 2016 - Issue 1
Published by "Mircea cel Batran" Naval Academy Press, Constanta, Romania // The journal is indexed in: PROQUEST / DOAJ / DRJI / JOURNAL INDEX / I2OR / SCIENCE LIBRARY INDEX / Google Scholar / Crossref /

Academic Keys / ROAD Open Access / OAJI / Academic Resources / Scientific Indexing Services / SCIPIO
\end{abstract}

\title{
NATO SPECIFIC EVIDENCE IN HIGHER EDUCATION OF MARINE
}

\author{
Virgil ENE-VOICULESCU ${ }^{1}$ \\ Ion LAZAR ${ }^{2}$ \\ ${ }^{1}$ Professor Ph.D., Naval Academy, Constanta, Romania \\ ${ }^{2}$ Lecturers Ph.D., Naval Academy, Constanta, Romania
}

\begin{abstract}
These papers contain the main of introduction the NATO contribution in our instructional navy education. In this respect we won't to promote a new sports and physical education curricula for the students, according with NATO standards.
\end{abstract}

Key words: sport and physical education, obstacle swimming, navy education, NATO contribution, instructional programs

\section{INTRODUCTION}

Settlement scientific substantiation for practicing physical education and military will lead the continuous improvement of tertiary students aware of marine and teachers of physical education and sport this field. The concept of military physical education, materialized by a model of a complex and dynamic system has its own characteristics and peculiarities. Thus, by the wide range of specific means this discipline demonstrates its viability in the curricula of military higher educational institutions. Character flexible and permanent openness of physical education is given by the goals pursued the physical education and sports, namely regulation and self-regulation in psychomotricity plan; receiving, processing and issuing responses neuropsychomotor.

\section{OBJECTIVES OF SPORT AND PHYSICAL \\ EDUCATION IN PHYSICAL EDUCATION \\ MILITARY SUBSYSTEM}

Military higher education system on the basis of vast accumulations methodological and organizational specialists in the field have shaped the social importance of discipline - physical education and sport, whose tasks are included in general objectives of the formative process of military higher education system.

Regularities and principles governed the system of military physical education meet the following objectives:

- Strengthen and maintain sane-genesis;

- Harmonious physical development;

- Develop basic motor skills of the student regardless of their forces to which it belongs;

- Forming a complex system of motion skills and, specific applications military system;

- Forming the habit of practicing physical exercise to maintain health, leisure and maintaining the capacity to fight;
- Capacity intellectual, moral and emotional volitional by type specific training temperamental military student.

- Awareness of the need to mentally systematic practice of physical exercise in order consecration professional.

Military Physical Education begins with psychomotor values of students and military personnel assigned to limits on age groups, reporting permanently to the objectives and contents of the syllabi. The objectives set out above is achieved by specific disciplines that have a pronounced applicative military provided the syllabus specific military physical education and sport. These disciplines are: self- defense, applied swimming, military applicative pathways, climbing, skiing applicative skydiving. CONTENT

The pyramid structure expertise, an important role is assigned to design teaching methodology. The content of this methodology will be permanently shifted depending on the specific evidence military applications.

In the context of Euro-Atlantic integration of applied military sports activity requires a reorganization of teaching design methodology. Implementation Strategy of teaching - learning consolidation - improve driving skills, setting objectives, tasks and implicit themes of the lesson of physical education and sports training will be selected based. They will be selected based on practical military characteristics.

Wishing to reconsider military physical education content, raising the share of applied disciplines, this paper proposes a reorientation of thematic curriculum. In this sense the lessons of physical education and sport will benefit from an extensive thematic military pentathlon discipline. 
"Mircea cel Batran" Naval Academy Scientific Bulletin, Volume XIX - 2016 - Issue 1

Published by "Mircea cel Batran" Naval Academy Press, Constanta, Romania // The journal is indexed in: PROQUEST / DOAJ / DRJI / JOURNAL INDEX / I2OR / SCIENCE LIBRARY INDEX / Google Scholar / Crossref /

Academic Keys / ROAD Open Access / OAJI / Academic Resources / Scientific Indexing Services / SCIPIO

It is known that the Romanian military pentathlon became a necessity imposed by modernizing and adjusting the military system requirements and international social policy. Military pentathlon area has grown dramatically internationally from one edition to the next European Championships and World Championships.

\section{SWIMMING 50M HURDLES}

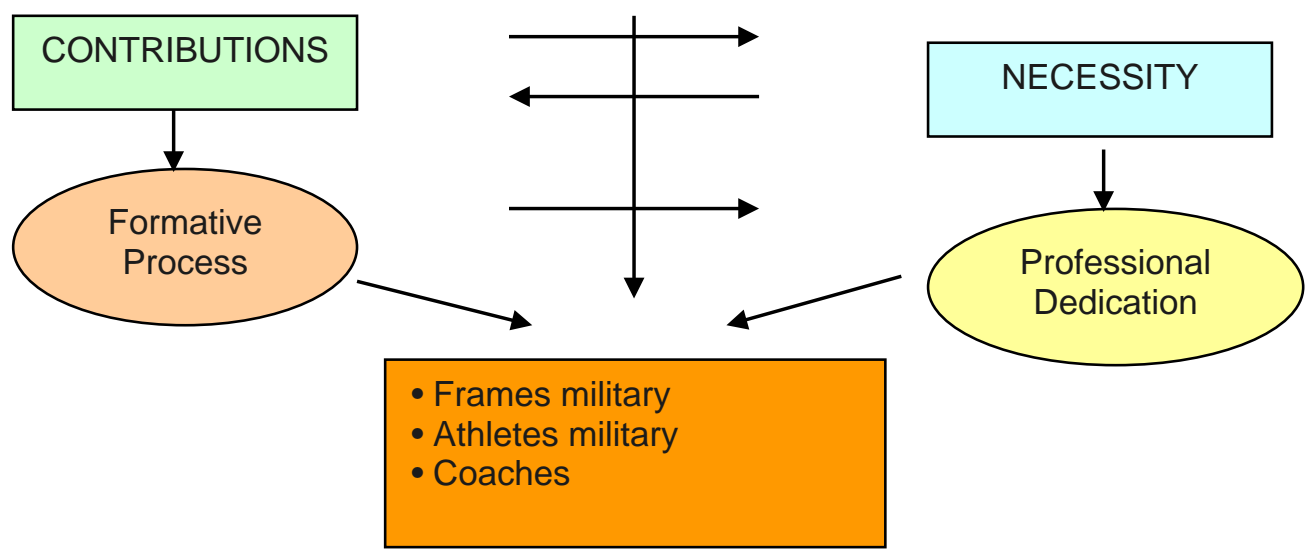

Figure1. Diagram of correspondence

Most often military pentathlon is included in the Military World Games (Rome, 1995; Zagreb, 1999; Catania, 2003). Samples of this discipline (shooting, obstacle course, swimming 50m hurdles, grenade throwing, and running in varied terrain $8 \mathrm{~km}$ ) evolved both in technical input, especially performance. Based on these allegations consider appropriate amendments to the planning level students from military higher educational institutions for the purposes of implementing the thematic lessons of the most spectacular events: swimming 50m hurdles .

If in regard to changing teaching strategies and teaching design decision rests with each specialist based in part depending on the material and students' individual qualities, changing content planning can be done only based on experimental studies truthful.

Understanding of phenomena corollary of the above, we propose the following sequence correlation (Figure 1) that express, as diagram a movement, whatever the swimming 50m hurdles would mean introducing syllabus content in shifting to higher education for marine.

\section{BIBLIOGRAFY}

[1] Appendix Military Pentathlon, 1985; 1990; 1995; 2001.

[2] Ene V., New orientation in military pentathlon training, Constanta, 2003 